\title{
Weakness in HK Currency Board System and Trading Opportunities in Betting A De-Peg of the Hong Kong Dollar
}

\section{Those whom the gods wish to destroy, they first make mad-Euripides}

Kun Li

Research Analyst, Selerity Inc, New York City, USA

Tel: 1-518-203-8247Ｅ-mail: Lincoln.Kun.Li@Gmail.com

Received: February 23, 2017 Accepted: March 7, 2017 Published: March 23, 2017

doi:10.5296/ifb.v4i1.10969＜noBreak>ＵRL: http://dx.doi.org/10.5296/ifb.v4i1.10969

\begin{abstract}
Hong Kong (HK) adopted the Linked Exchange Rate (LER) system in 1983, and it has been operating successfully for more than three decades. However, the maintenance costs for the LER system have grown exorbitantly and could outpace the costs of an exit, especially under the combined influence of a slow-down of the Chinese economy and a possible interest rate hike in the U.S. The HK government currently holds much more foreign reserves than it did preceding the 1997 Asian Financial Crisis. The HK government is also facing political unrest and growing anger of low income residents towards wealth inequality. This opposition could eventually force the HK government to abandon the Currency Board System. At present, the cost of exiting the LER -system is small thanks to a strong HKD sustained by large capital inflows from mainland China. However, the time frame for such a low-cost exit is short.

In our view, the HK government is likely to maintain the current system, even at high social and economic costs, in the expectation that changing external factors, such as the rebound of the Chinese economy, will relieve the de-pegging pressure. In this report, we explore several approaches to gauge the timing and risks of a de-pegging of the HKD and the collapse of the Chinese housing bubble. At the same time, we analyze the potential impact of a de-pegging on HK's local companies and the most vulnerable parts of the system.
\end{abstract}

Keywords: HKMA, PBOC, Currency Board System, Double-down Strategy, HKD, USD 


\section{Background to Hong Kong Adopting the Current Linked Exchange Rate System}

Hong Kong adopted its current Linked Exchange Rate system in 1983 after an "unfavorable" discussion between Margaret Thatcher and Deng Xiaoping concerning the proposal that the British government continue to manage HK after 1997. The concern over the ruling on the part of the Chinese Communist Party drove capital out of HK and the Chinese government's threat to take over HK before1997 exacerbated the trend. Prior to 1983, the HK government adopted a floating exchange rate system and as it lacked a central bank, the HKD depreciated quickly against the USD and inflation skyrocketed. In order to control inflation and restore discipline in the financial system within a short period of time, the HK government adopted the Linked Exchange Rate system. In essence this is a Currency Board System (Hanke, 2002) and at the same time, the HK government announced it had pegged the HKD to the USD at 7.80. At the time, there were few alternative options and there was an urgent time frame (Latter, 2007).

The system operated successfully for 30 years and it was resilient to several financial crises including the Asian Financial Crisis in 1997 and the more recent global financial crisis in 2008. The HK government claims its currency arrangements are the cornerstone of HK's prosperous economy and it argues that as a small open economy, the Currency Board System is the best choice for Hong Kong. Although the Currency Board System has contributed greatly to the prosperity of HK's economy in the past, when the environment changes, even the best functioning system may reveal weaknesses and the system may face the fate of abandonment. This is highly likely to apply to HK's Currency Board System. In the next section the arguments why the Hong Kong Monetary Authority (HKMA) should maintain the current system are examined and an assessment is made as to whether these arguments are still valid.

The HKMA claim that "the Linked Exchange Rate (LER) remains the best monetary option for Hong Kong and no other monetary policy would provide the stability and confidence necessary for an extremely open and externally oriented economy like Hong Kong” (HKMA, 2011)

In its introductory document to the existing currency system, the HKMA acknowledges the weakness of the LER but argues that the LER is still the best choice for HK after comparing it to alternative options including dollarization, free float, link to a basket of currencies, link to another currency, and link to the US dollar but at another rate (HKMA, 2011). Although the HKMA's argument has some merit, the HKMA does not discuss the option of adopting the monitoring band mechanism which has been adopted by Singapore, another highly successfully small and open economy in Asia. It is relevant that there are several research papers which show that adopting a monitoring band system would been even better option for HK.

Professors Rajan \& Siregar argue that Singapore' monitoring band system is more flexible and that it has "outperformed" HK's Currency Board System overall. The advantage of Singapore's system was more obvious in the 1990s when a series of external shocks hit the region and impacted both economies. They point out that when an economy is faced with a 
sharp external shock, it may require some degree of discretion to mitigate the effects of these shocks. The required internal adjustments are extremely costly and therefore they are not always forthcoming. The Currency Board System is a severe liability to HK because a failure to undertake the necessary adjustments will lead to loss of price competitiveness in international markets and a build-up of imbalances. This also encourages markets to test the durability of the peg which only exacerbates the problems. On the other hand, if the monetary authority adopts discretionary monetary policy, it would undermine the credibility and concomitant benefits of the hard peg. Hong Kong pursued such a discretionary policy in the 1990s, resulting in a sustained attack on the Hong Kong dollar in the midst of the crisis. (Rajan \& Siregar, 2002)

Professors Tse and Yip's research on interest rate behavior in two economies also shows that the monitoring band system in Singapore not only allows a greater flexibility in the choice of the exchange rate, but also a greater autonomy in the choice of interest rates to mitigate a crisis, recession or overheating. The loopholes and de-pegging risks of the currency board might imply a substantial exchange-rate risk for banks when conducting uncovered interest arbitrage. As a result, during the previous crisis period, banks refrained from performing arbitrage, despite the emergence of a huge interest rate differential between HK and the US during the crisis period. (Tse \& Yip, 2006)

HKMA also claimed "structure of Hong Kong economy is flexible and responsive. Markets such as the labor market, property and retail markets respond quickly to changing circumstances: this flexibility facilitates adjustments in internal prices and costs, which in turn bring about adjustments to external competitiveness without the necessity of moving the exchange rate." (HKMA, 2011)

However, such assumption might also not be true. Professor Yip suggests that, in fact, HK's (export) price was far more sluggish than that presumed by the proponents of HK's Currency Board System. Through research, he found that the long-perceived high flexibility in HK was in fact due to a high adjustment speed in quantity, not price. The adjustment in quantity implies a large adjustment cost in maintaining the peg in HK. This also explained why the volatility of HK's quantity (such as real GDP or export-volume) was unusually large by international standards. Yip found that prior to the 1997 Asian Financial Crisis, HK had experienced years of inflation and the fixed exchange rate had pushed HK's prices and wages to extremely high levels. Therefore, even HK experienced more than five years of deflation, although the accumulated fall in prices and wages during the post-crisis recession is still small when compared with the accumulated rise during the 7-8 years of asset inflation before late-1997. Yip's research suggests that the accumulated rise in HK's Consumer Price Index (CPI) between January 1990 and December 2003 is still substantially higher than that of the US and indicated that there could still be plenty of down side for HK's prices and wages. (Yip, 2005)

The sluggishness associated with adjusting wages and prices might be even worse at present compared to the last decade. The gap between the rich and poor of $\mathrm{HK}$ is among the widest in the world, and the problem is only getting worse. Monthly median earnings have only 
increased by $30 \%$ over the last 10 years, while Hong Kong's GDP has jumped 60\%. (CNN, 2014) Low income residents are becoming angrier about the growing inequality of wealth and populist political sentiment makes it harder to make necessary wage and price adjustments. A good example is that HK dock workers organized a strike against Hutchison Whampoa Group and asked for a $23 \%$ pay increase which finally ended up being a $9.8 \%$ pay rise backdated to 2013. (Financial Times, 2013) It is unimaginable that low income workers will accept pay cuts or high unemployment when another crisis breaks out. It is this social and political pressure that could be "the last straw that breaks the camel's back" in terms of the HK government maintaining the Currency Board System.

\section{The Worst Scenario}

As monetary policies among the major central banks diverge and the Chinese economy is slowing down, the HKMA recently conducted research on the "worst case" scenario and it has been endeavoring to determine the combined impact.

As Hong Kong has adopted the Currency Board System, US monetary policy mainly affects interest rate-sensitive sectors. Quantitative easing (QE) by the European Central Bank (ECB) and the Bank of Japan (BoJ) reinforces appreciation pressures on the HKD. On the other hand, it also somewhat neutralizes capital outflows caused by a tightening in US monetary policy. The divergence of major central bank policies has caused the growth in real GDP to slow down and the unemployment rate to go up. However, real variables such as real GDP growth and the unemployment rate are more sensitive to the economic slowdown in Mainland China. With shocks emanating from the slowdown in the Mainland, the growth in real GDP falls further and unemployment rises by more. (Chen \& Tsang, 2016) Although the HKMA's research suggests that the current financial system can again sustain such shocks, it would be the social and political pressures that lead to the exit from the Currency Board System.

\section{Exiting Timing}

Just as Professors Rajan \& Siregar point out, the orchestration of an exit from the Currency Board System is a difficult maneuver which could be destabilizing, especially considering that HK authorities have invested a great deal of resources in rebuilding confidence in the currency board arrangements following the regional financial crisis. Although the maintenance costs might outpace the exit costs, one cannot be sure if the end game is necessarily worth it. (Rajan \& Siregar, 2002)

Professor Yip suggests that although the exit cost is unknown, a stronger currency can mitigate the cost. He argues that if the US dollar enters a period of substantial depreciation and if the HK dollar is unpegged at this point, then the exit costs will be very small (or even negative) with the dollar up against USD-related currencies and relatively stable against other currencies. (Yip, 2005)

At present although the timing of an exit from the currency peg is not at its best, it is also not at its worst. Thanks to capital flows from mainland China, the HK dollar is currently in a stronger zone. 


\section{Macrothink}

In its half-year monetary and financial stability report, the HKMA suggests that after the PBOC depreciated the RMB against the USD last August, investors converted their offshore RMB into HKD. Consequently, strong-side Convertibility Undertakings (Note 1) (CUs) were being triggered repeatedly between 1 September and 30 October 2015. The strong inflow totaled HK\$155.7 billion. (HKMA, 2016)

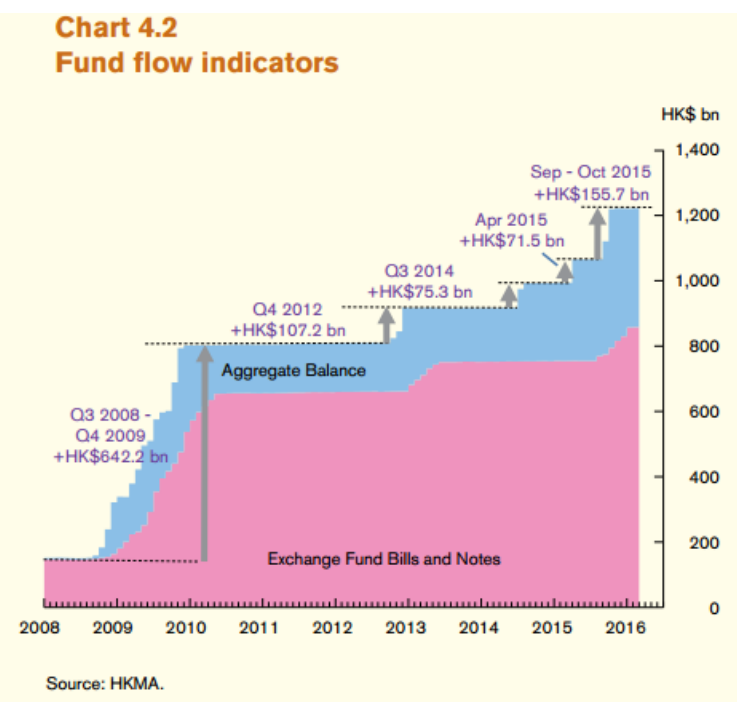

Figure 1. Fund flow indicators

However, the slowing down of the Chinese economy might be a double edge sword for the HKD FX rate. In January, the HKD dropped by as much as 0.28 percent, its biggest intra-day fall since October 2003 and speculation mounted in the options market that the city's 32-year-old currency peg would end as investors lost confidence in Chinese assets. (Market Pulse, 2016)

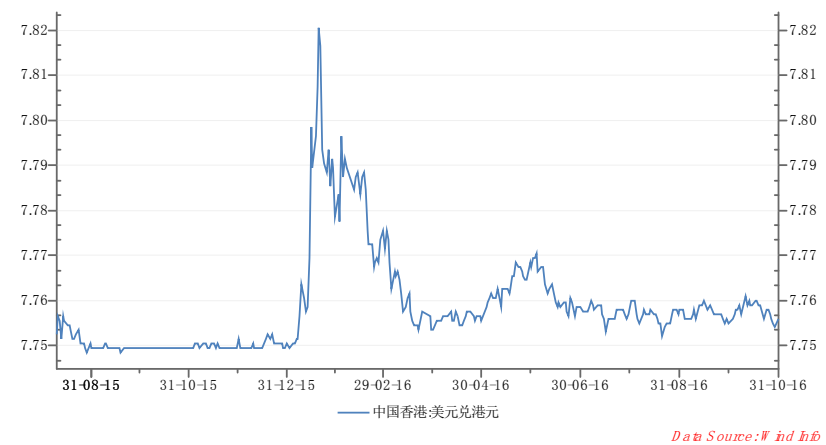

Figure 2. US Dollar (USD) to Hong Kong Dollar (HKD) 
It might be of best interest for Hong Kong to abandon the currency board system sooner. However, just as Professor Mishkin suggests: "It is exactly when things are going well that smooth transition out of the currency board is feasible. On the other hand, this is when the political will to exit from the currency board may be the weakest, even if the country would be better served by a different monetary regime.” (Mishkin, 2009) Unfortunately, governments frequently lack the capacity to choose the best options. Therefore, the HK government is likely to maintain the current system, even at a high social and economic cost, in the expectation that the environment will change and relieve it from pressure. This could happen, for example, if the Chinese economy rebounded.

\section{Speculation Timing}

Choosing the best timing is the most critical aspect of short sellers' behavior when speculating on a HKD de-pegging, especially considering the HK government owns huge amounts of foreign reserves and has the capacity to generate support from the Chinese central government. A fundamental practice is to check Hong Kong's trade environment. There are two methods: the first one is to use residency-based Balance of Payments (BOP) data and the second method is to use currency-based BOP data. However, each method has its own shortcomings due to the special status of Hong Kong as an international financial center. (Cheung, Chow, \& Yiu, 2015)

An alternative solution is to assess the credibility of the Hong Kong currency peg through comparing interest rates differences between $\mathrm{HK}$ and the U.S. Fung and Yu applied a Bayesian framework to the Svensson test. (Fung \& Yu, 2007) Rather than simply addressing whether the Convertibility Zone is either fully credible or non-credible, the Bayesian approach provides time-varying estimates about the evolution of the degree of credibility of the Convertibility Zone at each point in time. (Hui, Lo, \& Fong, 2015) Their work results shows as follows. 
(a) Weak-side Convertibility Credibility (Prob $\left.\left\{\mathcal{Z}_{u} /\left(1 \mathrm{H}^{\prime \prime \prime}{ }_{u}\right) \mathrm{t} 0 \mid z_{u, t}, z_{u, t \hat{H}}, \ldots, z_{u, 1}\right\}\right)$

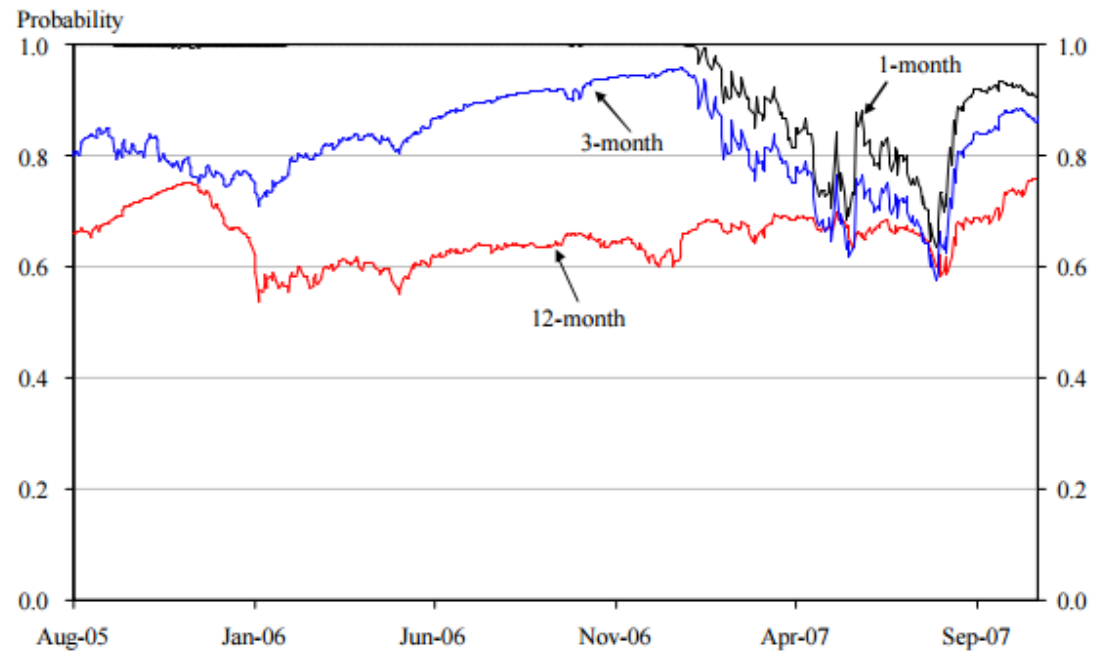

(b) Strong-side Convertibility Credibility (Prob $\left.\left\{\mathrm{Z}_{l} /\left(1 \mathrm{H}^{\prime \prime \prime}{ }_{l}\right) \mathrm{f} 0 \mid z_{l, t}, z_{l, t} \hat{H}_{1}, \ldots, z_{l, 1}\right\}\right)$

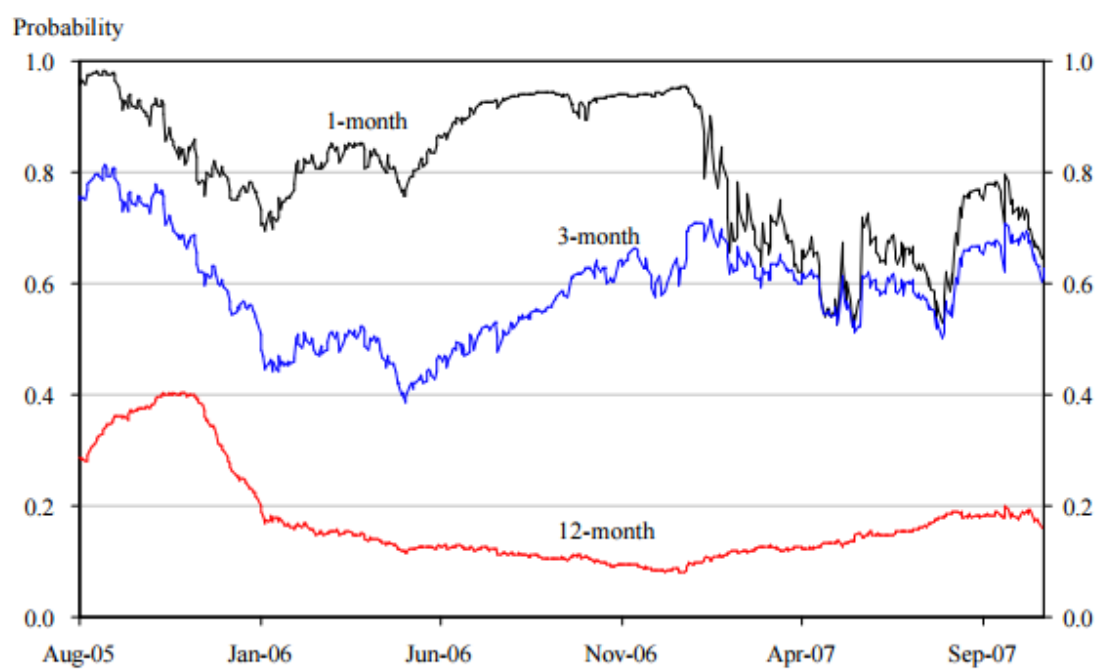

Figure 3. Weak and strong-sides convertibility credibility

In 2015, the Swiss National Bank (SNB) had claimed "with utmost determination" that it would buy foreign currency "in unlimited quantities" (Note 2) and broke its promises. HKMA's research into the event is worth paying special attention to as the Institute made a similar promise. Hui, Lo, \& Fong studied the dynamics of the Swiss Franc and used market data to calculate the drift term and stochastic process. Their research is based on the assumption that the speed of the mean-reverting drift is estimated as a function of increasing foreign reserves. Through research on the drift strength, when the Swiss Franc was at its strong point, their result shows the condition for breaching the limit was met in November 2014, about two months before the SNB abandoned the limit. (Hui, Lo, \& Fong, 2015) A 
similar process might also be suitable in studying the HKD.

Monitoring HK fundamentals is important, however, investors have to consider the "honeymoon effect" and the Krugman-type target-zone models which suggest that the exchange rate function will appear to be less sensitive to changes in fundamentals than the corresponding free-floating exchange rate. The effect of fundamentals on the exchange rate decreases when the exchange rate deviates from its central parity. (Hui, Lo, \& Fong, 2015)

However, the HKD is heavily reliant on China's economy. During January 2016, the huge movement in the HKD has little to do with fundamentals in Hong Kong but it correlates with changes in the mainland. The Chinese housing bubble is regarded as the Sword of Damocles to the Chinese economy and a collapse of the Chinese housing bubble might destroy investors' confidence in the HKD. Therefore, gauging and estimating the timing of the collapse of the Chinese housing bubble might be more important.

In measuring the Chinese housing situation, the price of housing is an important parameter. However, the Chinese official data is well-known for its poor quality, and especially the high-profile housing price data. In order to solve this issue, Deng, Girardin, \& Joyeux in their research papers offered a creative way to measure housing prices using highly frequent transaction data. (Deng, Girardin, \& Joyeux, 2015)

After solving the price data issue, investors need to model the dynamics of Chinese housing development. However, the increase in Chinese housing prices has come about in conjunction with fast economic development and there are disputes about whether China's rapidly increasing housing prices indicate a bubble. Yang \& Gete conducted research which suggested that productivity, savings gluts, and tax policies, are the key drivers. They pointed out that productivity and land shocks affect housing quantities more than prices, while tax policies and savings glut shocks affect house prices more than quantities of houses available for sale. However, when the sample focus is closer to 2014, housing preferences and credit shocks become increasingly important in explaining house prices and volume, while population shocks explain a larger share of the dynamics of residential investment. During 2016, the credit shock might have played an even greater role, especially considering that residential mortgages became a major driver of Chinese new credit and accounted for $70 \%$ of new monthly loans by August 2016. (WSJ, 2016) As credit evolved into the dominant role, the high profile Asian hedge fund managers BeiLesi, which has just funded its own fund, Lingfeng Capital, leveraged the Log-Periodic Power Law (LPPL) model (BeiLesi, 2011) to predict the timing of the collapse of the housing bubble based on the assumption that in order to maintain such aPonzi scheme credit has to match the power law. (Note 3) 


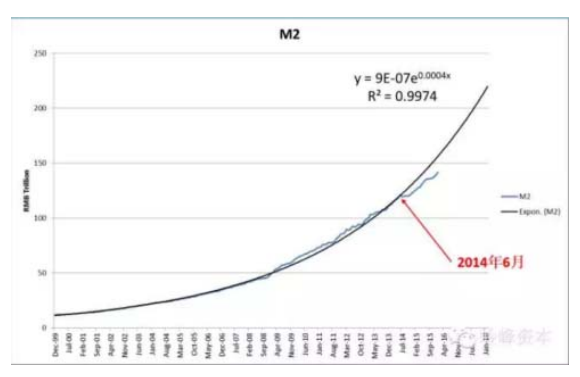

Figure 4. China M2 Growth Rate diverged from the Power Law

\section{Target Choosing}

When the de-pegging risk is measured by a market consensus, investors face choices when determining what to do next. Assessing the de-pegging impact on local firms and identifying the most vulnerable parts of the system are thus critical.

Previous financial crises in Hong Kong have usually related to housing bubbles and banks' unrestricted lending. (Goodstadt, 2007) When de-pegging risks emerge, banks are highly likely to become the first choice for short sellers. However, the recent control of Loan-to Value measures has reduced the exposure of banks in the real estate sector (Wong, Tsang, \& Kong, 2014) and there is a possibility that the Hong Kong government will depart from its Laisser faire policy and directly support banks, considering that non-interventionism in Hong Kong has never been a matter of economic conviction but primarily a question of political convenience. (Goodstadt, 2010)

The recent development of Hong Kong's bond market might provide better goals. Banks used to be the dominant financial intermediaries in Hong Kong, however, the growth of the corporate bond market has accelerated considerably. After the 2008 financial crisis, outstanding corporate bonds posted a significantly faster growth rate of $17 \%$ per annum on average, far outpacing economic growth. It is appropriate to recall the quote on the front of this report: "Those whom the gods wish to destroy, they first make mad”. BIS has already shown its concerns over such fast development of Hong Kong's bond market. (Leung, Hui, \& Fong, 2015) The bank pointed out that bond issuers are less confined to corporates with top credit ratings and corporations with lower credit ratings are now able to gain access to the bond market. Also as the pricing of corporate bonds are usually based on major government bond yields (notably the US Treasury yields), the increased use of bond financing could make corporate borrowing costs more sensitive to global monetary and financial conditions. There are also huge mismatches of currency due to the low cost of issuing USD denominated bonds instead of HKD denominated bonds. As of the end of 2014, the outstanding amount of corporate bonds in Hong Kong stood at US\$101.8 billion, of which 14\%, 65\% and 22\% were denominated in HKD, USD and other currencies respectively. (Leung, Hui, \& Fong, 2015) When the crisis emerges, these low credit companies with large outstanding USD denominated bonds are expected to be hit hard as de-pegging will not only hit their balance sheets but also worsen their financing situations due to their inverted capital structures. (Pettis, 
2001) Also compared with the U.S. bond market, the Hong Kong bond market is narrow and the spreads quoted are quite wide which also facilitates an attack by short sellers. (Latter, 2008)

The development of the bond market is also limited by the government's capacity to support the HKD as corporate bond issuers might be unable to tolerate swings in short-term rates. A similar case occurred back in the early-1990's with the British Pound when the credibility of the commitment of the Bank of England to support sterling was limited due to the fact that $90 \%$ of home mortgage loans were issued at floating interest rates rather than fixed interest rates. (Corsetti, Pesenti, \& Buiter, 2001) On the other hand, the Swedish central bank raised the interest rate to 75 percent (annualized) and limited the incentive to borrow weak currencies for speculative purposes and successfully rebuffed George Soros. (Corsetti, Pesenti, \& Buiter, 2001)

As the Hong Kong government is highly likely to choose to support the current system, investors need to be alert to the government's intervention and the ensuing trading opportunities. In this regard, a case study can be insightful. During the 1997 Asian financial crisis, the Hong Kong government spent hundreds of billions of HKD in supporting the market. Although no details have been revealed, Goodhart reviewed the government's strategy based on an intensive study of market data and reports. (Goodhart \& Lu, 2003) His research showed that short sellers were highly leveraged and if speculators could push down the stock index by 1000 points within 100 days, the cost would be HKD 400 million and the net profit would be HKD 3.6 billion. In order to foil the speculators' double-down strategy, the Hong Kong government conducted a counter double-play strategy, not only in the Hong Kong market but also in the London market as many Hong Kong stocks are listed on both stock exchanges under different currencies. The fierce confrontation between the two sides created huge arbitrage opportunities. For example, during the two days before the August index futures expired, the prices of the London GBP trading with HSBC dropped considerably while the London HKD trading with HSBC and the HKD trading with HSBC remained much higher. (Goodhart \& Lu, 2003) When similar scenarios emerged, investors who carefully studied reviews of previous interventions and used their discretion in judging the circumstances were the most likely to grasp trading opportunities, especially considering that when under extreme stances, many algorithim arbitrage trading strategies had to turn down due to huge de-pegging risks.

\section{Conclusion}

In our view, the HK government is likely to maintain the current currency board system, even at high social and economic costs, in the expectation that changing external factors, such as the rebound of the Chinese economy, will relieve the de-pegging pressure. There are several approaches to gauge the timing and risks of a de-pegging of the HKD and the collapse of the Chinese housing bubble. The fast developed Hong Kong local bond market might be the best target for short sellers. 


\section{References}

BeiLesi. (2011). The bubble is Ripe. Caixin. [Online] Available: http://barrons.blog.caixin.com/archives/24765

Chen, H., \& Tsang, A. (2016). The Impact of U.S Monetary Policy And Other External Shocks On The Hong Kong Economy: A Factor-Augmented Var Approach. HKIMR Working Paper No.09/2016. [Online] Available: https://www.hkimr.org/uploads/publication/443/wp-no-09_2016.pdf

Cheung, Y. W., Chow, K. K., \& Yiu, M. S. (2015). The Nexus Of Official And Illicit Capital Flows-The Case Of Hong Kong. HKIMR Working Paper. No.25/2015. [Online] Available: http://www.hkimr.org/uploads/publication/431/wp-no-25_2015.pdf

CNN. (2014). Hong Kong's growing wealth gap fuels protests. [Online] Available: http://money.cnn.com/2014/11/06/news/economy/hong-kong-income-inequality/

Corsetti, G., Pesenti, P., \& Buiter, W. (2001). Financial Markets and European Monetary Cooperation: The Lessons of the 1992-93 Exchange Rate Mechanism Crisis (pp. 57-58). Cambridge: Cambridge University Press.

Deng, Y., Girardin, E., \& Joyeux, R. (2015). Fundamentals and the Volatility of Real Estate Prices in China: A Sequential Modelling Strategy. HKIMR Working Paper. No.22/2015. [Online] Available: http://www.hkimr.org/uploads/publication/428/wp-no-22_2015.pdf

Financial Times. (2013). Hong Kong dock workers end strike after pay deal. [Online] Available: http://www.ftchinese.com/story/001050316/en

Fung, L., \& Yu, I. (2007). Assessing the Credibility of The Convertibility Zone of The Hong Kong Dollar. HKMA Working Paper No.19 /2007. [Online] Available: http://www.hkma.gov.hk/media/eng/publication-and-research/research/working-papers/HKM AWP07_19_full.pdf

Goodhart, C., \& Lu, D. (2003). Intervention to Save Hong Kong: Counter-Speculation in Financial Markets (pp. 39-96). Oxford: Oxford University Press.

Goodstadt, L. F. (2007). Profits, Politics, and Panics: Hong Kong's Banks and the Making of a Miracle Economy, 1935-1985 (pp. 163-181). Hong Kong: Hong Kong University Press.

Goodstadt, L. F. (2010). The Global Crisis: Why Laisser-faire Hong Kong Prefers Regulation. HKIMR Working Paper No.01/2010. [Online] Available: http://www.hkimr.org/uploads/publication/109/ub_full_0_2_234_wp-no-01_2010.pdf

Hanke, S. (2002). On Dollarization and Currency Boards: Error and Deception. Policy Reform, 5(4), 203-222. https://doi.org/10.1080/1384128032000096814

HKMA. (2011). HKMA Background Brief No.1 Hong Kong's Linked Exchange Rate System (2nd ed.). [Online] Available: http://www.hkma.gov.hk/media/eng/publication-and-research/background-briefs/hkmalin/full _e.pdf 
HKMA. (2016). Half-Yearly Monetary and Financial Stability Report March 2016. [Online] Available:

http://www.hkma.gov.hk/media/eng/publication-and-research/quarterly-bulletin/qb201603/E_ Half-yearly_201603.pdf

Hui, C. H., Lo, C. F., \& Fong, T. (2015). A Quasi-Bounded Model for Swiss Franc's One-Sided Target Zone During 2011-2015. HKIMR Working Paper. No.15/2015. [Online] Available: http://www.hkimr.org/uploads/publication/421/wp-no-15_2015-final-.pdf

Latter, T. (2007). Hong Kong's Money: The History, Logic and operation of the Currency Peg (p.55). Hong Kong: Hong Kong University Press.

Latter, T. (2008). What Futures for The Hong Kong Dollar Corporate Bond Market? HKIMR Working Paper No.19/2008. [Online] Available: http://www.hkimr.org/uploads/publication/154/ub_full_0_2_188_hkimr_no19_bw.pdf

Leung, D., Hui, C., \& Fong, T. (2015). The rise of Hong Kong's corporate bond market: drivers and implications. BIS Papers No 83. [Online] Available: http://www.bis.org/publ/bppdf/bispap83i.pdf

Market Pulse. (2016). HKD Drops Most Since '03. [Online] Available: http://www.marketpulse.com/20160114/hkd-drops-most-since-03/

Mishkin, F. (2009). Monetary Policy Strategy (p. 456). Cambridge: The MIT Press.

Pettis, M. (2001). The Volatility Machine: Emerging Economics and the Threat of Financial Collapse (p. 132). Oxford: Oxford University Press.

Rajan, R., \& Siregar, R. (2002). Choice of Exchange Rate Regime: Currency Board (Hong Kong) or Monitoring Band (Singapore)? Australian Economic Papers, 41(4), 538-556. https://doi.org/10.1111/1467-8454.00179

Tse, Y. K., \& Yip, P. S. L. (2006). Exchange-rate systems and interest-rate behaviour: The experience of Hong Kong and Singapore. International Review of Economics \& Finance, 15(2), 212-227. https://doi.org/10.1016/j.iref.2004.11.004

Wong, E., Tsang, A., \& Kong, S. (2014). How Does Loan-To-Value Policy Strengthen Banks' Resilience to Property Price Shocks_Evidence from Hong Kong. HKIMR Working Paper No.03/2014. [Online] Available: http://www.hkimr.org/uploads/publication/374/wp-no-03_2014-final-.pdf

WSJ. (2016). China's Credit Fire Hose Floods Housing Market. [Online] Available: http://www.wsj.com/articles/chinas-credit-fire-hose-floods-housing-market-1473926793

Yip, P. S. L. (2005). On the Maintenance Costs and Exit Costs of the Peg in Hong Kong. Review of Pacific Basin Financial Markets and Policies (RPBFMP), 8(3), 377-403. https://doi.org/10.1142/S021909150500049X 


\section{Notes}

Note 1. "Under the strong-side Convertibility Undertaking, the HKMA undertakes to buy US dollars from licensed banks at 7.75. Under the weak-side Convertibility Undertaking, the HKMA undertakes to sell US dollars at 7.85.” HKMA. [Online] Available: http://www.hkma.gov.hk/gdbook/eng/c/convertibility_undertak.htm

Note 2. See the press release "Swiss National Bank sets minimum exchange rate at CHF 1.20 per euro" by the SNB on 6 September 2011. [Online] Available: http://www.snb.ch/en/mmr/reference/pre_20110906/source/pre_20110906.en.pdf

Note 3. Mr. Bei is using M2 data in his public article, however in China, the social financing data might be more insightful data and it's very likely Mr. Bei adopted such data in his trading model. Selerity Inc. has conducted an in-depth report on China's social financing data and full report can be access at https://sgi.seleritycorp.com/special-report-shadow-banking-the-chinese-money-supply/

\section{Copyright Disclaimer}

Copyright for this article is retained by the author(s), with first publication rights granted to the journal.

This is an open-access article distributed under the terms and conditions of the Creative Commons Attribution license (http://creativecommons.org/licenses/by/3.0/). 